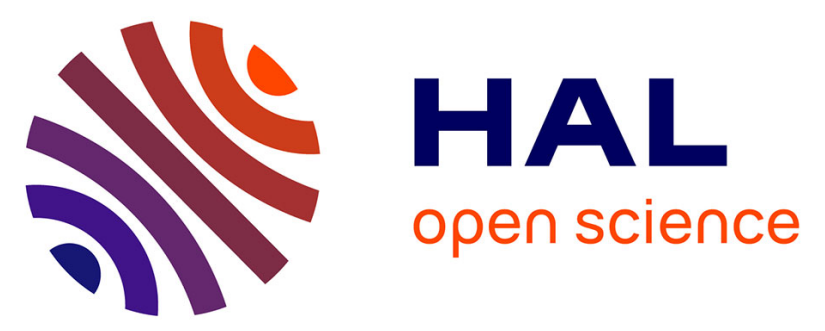

\title{
Factors associated with dementia among elderly people living in two cities in Central Africa: the EDAC multicenter study.
}

Maëlenn Guerchet, Alain Maxime Mouanga, Pascal M’Belesso, André Tabo, Bébène Ndamba-Bandzouzi, Moussiliou Noël Paraïso, Dismand Stephan Houinato, Pascale Cowppli-Bony, Philippe Nubukpo, Victor Aboyans, et al.

\section{To cite this version:}

Maëlenn Guerchet, Alain Maxime Mouanga, Pascal M'Belesso, André Tabo, Bébène NdambaBandzouzi, et al.. Factors associated with dementia among elderly people living in two cities in Central Africa: the EDAC multicenter study.. Journal of Alzheimer's Disease, 2012, 29 (1), pp.15-24. 10.3233/JAD-2011-111364 . hal-00933435

\section{HAL Id: hal-00933435 \\ https://hal-unilim.archives-ouvertes.fr/hal-00933435}

Submitted on 7 Jan 2022

HAL is a multi-disciplinary open access archive for the deposit and dissemination of scientific research documents, whether they are published or not. The documents may come from teaching and research institutions in France or abroad, or from public or private research centers.
L'archive ouverte pluridisciplinaire HAL, est destinée au dépôt et à la diffusion de documents scientifiques de niveau recherche, publiés ou non, émanant des établissements d'enseignement et de recherche français ou étrangers, des laboratoires publics ou privés. 
Factors associated with dementia among elderly people living in two cities in central Africa: the EDAC Multicenter Study.

Maëlenn Guerchet, PhD 1; Alain M. Mouanga, MD 1,2; Pascal M'belesso, MD 1,3; André Tabo, MD 4; Bébène Bandzouzi, MD 5; Moussiliou N. Paraïso, PhD 1,6; Dismand S. Houinato, MD, PhD 1,7; Pascale Cowppli-Bony, MD, PhD 8; Philippe Nubukpo, MD, PhD 1,9; Victor Aboyans, MD, PhD 1,10; Jean-Pierre Clément, MD, PhD 1,9; Jean-François Dartigues, MD, PhD 8; Pierre-Marie Preux, MD, PhD ${ }^{1,11 .}$

1 - INSERM U1094, Tropical Neuroepidemiology, Limoges, France; Univ. Limoges, School of Medicine, Institute of Tropical Neurology, Limoges, France; CHU Limoges, France.

2 - Dept. of Psychiatry, Brazzaville University Hospital, BP32 Brazzaville, Congo;

3 - Dept. of Neurology, Amitié Hospital, BP 3183 Bangui, Central African Republic;

4 - Dept. of Psychiatry, Bangui National Hospital, BP911; Bangui, Central African Republic;

5 - Dept. of Neurology, Brazzaville University Hospital, BP32 Brazzaville, Congo;

6 - Regional Institute of Public Health, Ouidah, 01BP918 Cotonou, Benin

7 - Abomey Calavi University, Faculty of Health Sciences, Neurological Teaching and Research Unit, 04BP76 Cotonou, Benin ;

8 - INSERM U897, Victor Segalen Bordeaux II University, Bordeaux, 33076 France ;

9 - Dept. of Memory Research, Limoges University Hospital, Esquirol Hospital; 15

rue du Dr Marcland, 87025 Limoges, France;

10 - Dept. of Cardiology, Dupuytren University Hospital, 2 avenue Martin Luther King, 87042 Limoges, France; 
11 - Dept. of Medical Information \& Evaluation, Clinical Research and Biostatistic Unit, University Hospital; 2 Avenue Martin Luther King, 87042 Limoges, France

Running title: Factors associated with dementia in Central Africa.

Correspondance to: $\quad$ Pr Pierre-Marie Preux

Institut de Neuroépidémiologie et de Neurologie Tropicale

Faculté de Médecine, 2 rue du Docteur Marcland

87025 Limoges, France

Tel: +335554358 20, Fax: +33555435821

E-mail:preux@unilim.fr 


\section{ABSTRACT}

Risk factors for dementia in American and European countries have been well investigated. However, little research has been carried out in sub-Saharan Africa, where life events as well as environmental, socio-economic and modifiable risk factors (i.e. cardiovascular risk factors) may differ.

Two cross-sectional surveys were conducted in representative samples of the older general population living in Bangui (Central African Republic) and Brazzaville (Congo). Dementia was defined according to the DSM-IV criteria. Multivariate regression analyses were performed in order to identify independent factors associated with dementia.

Among the 977 elderly Africans included in this analysis, 75 (7.6\%) were diagnosed as having dementia. Increasing age, female gender, hypertension, a BMI $<18.5 \mathrm{~kg} / \mathrm{m}^{2}$, depressive symptoms and the lack of a primary education were significantly associated with dementia. Among life events, the death of one parent during childhood and recently having moved house were also associated with dementia.

Beyond the usual risk factors for dementia, this study highlights the role of stressful events in low-income countries. Factors associated with dementia in African countries seem different from established factors in high-income countries and require further investigation.

Keywords: dementia, Alzheimer's Disease, risk factors, Africa, epidemiology. 


\section{Introduction}

A few risk factors have been established for dementia. Ageing is the main one, with the prevalence of dementia roughly doubling every five years over the age of 65 [1]. Genetic causes have been found for Alzheimer's Disease (AD). Dementia has also been shown to be influenced by the environment, life events, and socio-economic and modifiable risk factors such as cardiovascular risk factors [2]. However, these epidemiologic data were provided by studies conducted in high-income countries. In contrast, in low-income countries, the epidemiology and risk factors of dementia are poorly studied. Regarding sub-Saharan Africa, studies carried out in Nigeria reported the significant association of older age and female sex with dementia and $A D$ $[3,4,5,6] . \mathrm{A} \mathrm{BMI}<18.5$ [6], living with others [5] and lifetime history of alcohol use [7] were also reported to be associated with $A D$, whereas a self-reported medical history of hypertension was found to be protective against incident $A D$ [6]. A lack of association between $\mathrm{AD}$ or dementia and the APOE $\varepsilon 4$ allele $[8,9]$ was reported in elderly Nigerians, and the allele was not linked with cognitive impairment in elderly Beninese people [10]. In the same populations, education was not significantly associated with dementia in multivariate analysis $[3,4,5,6,10]$. However, few subjects had an education beyond primary school in these studies.

The present study aimed to investigate factors associated with dementia in a crosssectional sample of elderly people living in two cities in Central Africa: Bangui (Central African Republic) and Brazzaville (Republic of Congo). We hypothesized that, given the particularities of living conditions in these countries, the factors associated with dementia in sub-Saharan African people may differ from those reported in high-income countries or other low-income countries. 


\section{Methods}

Study design

The EDAC (Epidemiology of Dementia in Central Africa) survey is a multicenter study carried out in Bangui and Brazzaville between September 2008 and March 2009. Bangui's population is estimated to be 622800 , including $1.4 \%$ aged $\geq 65$ years [11]. Brazzaville's population is about 1373 382, including $2.3 \% \geq 65$ years old [12]. Life expectancy at birth is estimated to be 48 years ( 49 for men and 48 for women) in the Central African Republic (CAR) whereas it is 55 (53 for men and 57 for women) in the Republic of Congo [13]. The main industries of Congo are linked to oil and wood, other industries are poorly developed and of only local importance. Forestry and mining are the only developed industries in CAR; there are essentially no others. The Human Development Index is $179 / 182$ for CAR and 136/182 for Congo [14].

Cross-sectional surveys among the general population were conducted in the $3^{\text {rd }}$ district of Bangui and the $4^{\text {th }}$ district of Brazzaville, using a door-to-door approach. The estimated populations of elderly people in the $3^{\text {rd }}$ and 4th districts of Bangui are 2603 (45\% men) and 3911 (44\% men), respectively [11, 12]. Each house visited was marked by the investigators (name of the study, number of the investigator and subject) with chalk, just above the door, ensuring exhaustive coverage, even in the absence of addresses. Town halls were informed of the study and district chiefs were visited prior to starting the screening in order to increase awareness of the study. Local associations were contacted and information broadcast on the radio. Participants were not remunerated, but a few basic drugs (such as analgesics and vermifuge) were distributed after physical examination if necessary. 
Multiethnic considerations (to avoid cluster effects) and feasibility guided the identification of participating districts. Approvals were obtained from ethical committees of the Central African Republic and Republic of Congo, supervised by the Ministries of Public Health or Scientific Research.

Subjects were required to be aged 65 years or older and to be currently resident in the area under study. Exclusion criteria were refusal to participate, and the presence of severe comorbidity precluding cognitive testing. Consent was obtained from the subject and/or family after explanation of the research goals, and before the interview.

\section{Dementia diagnosis}

All subjects aged 65 years or more and living in the study areas were contacted by the investigators and asked to participate in the research. If necessary, age was ascertained by official documents, from an informant or through a local event calendar. Age was estimated using two historical landmarks in each country (Congo: independence and Marien Ngouabi assassination; CAR: independence and Bokassa priesthood), using a validated method $[15,16]$.

Cognitive testing was performed using the Community Screening Interview for Dementia (CSI-D) [17] and the 5 Words Test (FWT) [18], adapted and pretested in the local languages (Sango, Lingala and Kituba). A relative of each elderly person included was interviewed at the same time using the CSI-D informant section to assess daily activities and any personality change. Every subject with a poor 
performance in the CSI-D cognitive tests $(<25.5 / 30)$ or the FWT (less than 10/10) was considered cognitively impaired and invited for further clinical assessment to confirm or rule out dementia.

This confirmation stage occurred during the weeks following the screening, at the hospital. Further psychometric tests were conducted, including the Free and Cued Selective reminding test [19], the Zazzo cancellation task [20] and Isaac's Set Test of verbal fluency [21]. Neurological examination was performed by neurologists, and stroke history and depressive disorders were sought. Orientation skills and daily activities were investigated in order to evaluate their dependency.

The diagnosis of dementia was made according to the DSM-IV criteria [22] and according to the clinical criteria proposed by the NINCDS-ADRDA (National Institute of Neurological and Communicative Disorders and Stroke and the Alzheimer's Disease and Related Disorders Association) for AD [23]. Diagnosis of other types of dementia (especially vascular dementia) was based on Hachinski Ischemic Scale [24], history of stroke and other clinical assessments. Medical records and test performances were reviewed by a group of experienced neurologists in uncertain cases and a consensus on the diagnosis was reached.

\section{Associated factors}

Sociodemographic data (i.e. marital status, schooling, occupation before retirement) and medical history (cardiovascular disease (CVD), head trauma, treatments if available, alcohol and tobacco consumption) were collected for each subject. Height $(\mathrm{cm})$ and weight $(\mathrm{kg})$ were measured in order to determine the Body Mass Index 
(BMI = weight divided by squared height). Hypertension was defined in terms of a reported history of hypertension and/or when systolic blood pressure at rest was $\geq 140 \mathrm{mmHg}$ and/or diastolic blood pressure was $\geq 90 \mathrm{mmHg}$. Diabetes was defined according to self-reported medical history or in cases of elevated capillary blood glucose level (Accu-Chek® Performa, Roche), above $140 \mathrm{mg} / \mathrm{dL}$ if the fasting period was $>2$ hours or above $200 \mathrm{mg} / \mathrm{dL}$ in non-fasting participants. Capillary blood cholesterol level was also determined (considered elevated if $>240 \mathrm{mg} / \mathrm{dL}$ ) (Accutrend® Plus, Roche). Goldberg's anxiety and depression scale was used [25]. The presence of 18 psychosocial factors was investigated for three different life periods (under 16 years old, between 16 and 64 years, 65 years and over) according to Persson and Skoog [26].

\section{Statistical analysis}

As the main goal of this survey was to estimate the prevalence of dementia [27], we aimed to include a minimum of 456 participants in each site in order to detect a prevalence of dementia of $5 \%$ with a precision of $2 \%$ (Epilnfo 6.04, Epiconcept).

The mean and standard deviation (SD) were used as summary statistics for quantitative variables (e.g. age), and compared using Student's t-test. Percentage counts were used for all qualitative variables of interest, and Fisher exact tests were used for comparisons. Level of significance for these comparisons was 0.05 .

Two separate multivariate regression analyses were conducted, using dementia as the dependent variable (reference group: subjects without dementia). Variables that had a $p$-value $\leq 0.25$ in the univariate analysis were included in multivariate logistic 
regression models. Backward stepwise procedures were realized, leading to final multivariate models with a level of significance of 0.05 . Confounding effects and interactions between independent variables in final models were examined. In the presence of interactions, odds ratios and their confidence intervals were determined for each group resulting from the interaction of the variables.

The first model was fitted using sociodemographic, medical and psychosocial data from before the onset of dementia as independent variables, and the second model included variables concomitant to the assessment of dementia.

Statistical analyses were carried out using $S A S \circledR$ software (version 9.2, SAS Institute, Cary, NC).

\section{Results}

Study population

During this study, 509 people aged 65 or more were contacted in Bangui and 546 in Brazzaville, of whom 496 and 520, respectively, agreed to participate ( $N=1016$; Figure 1). Fifty-nine percent of those studied were females (ratio M/F: 0.69), the mean age was $73.6 \pm 6.5$ years (range: 65 to 96 years) and $47.3 \%$ had primary school and higher education. Complete descriptions of the studied populations in each city are given in Table 1 .

After the screening phase, 188 (18.5\%) elderly subjects in Bangui and 148 (14.6\%) in Brazzaville were identified as cognitively impaired; 251 (74.7\%) were women. The 
mean age of cognitively impaired participants (75.7 \pm 7.2 years) was significantly higher than that of subjects free of cognitive impairment $(72.5 \pm 5.9)(p<0.0001)$.

Among the cognitively impaired subjects, 75 (7.4\%) were diagnosed with dementia after neurological examination; 57 (5.6\%) had probable or possible AD and $18(1.8 \%)$ had vascular dementia. Sixty participants with dementia were women (80.0\%). Mean age was $77.4 \pm 7.3$ and $18.7 \%$ of them were aged $\geq 85$ years. They were mostly widowed $(66.7 \%)$ and only $24.0 \%$ had been to primary school. Forty-eight $(64.0 \%)$ had hypertension, 10 (13.3\%) had diabetes and 68 (90.7\%) showed depressive symptoms at the time of the study.

Subjects with suspected cognitive impairment but not dementia were categorized separately. Thirty-eight participants $(3.7 \%)$ were lost between the two stages of the survey and could not be diagnosed (14 refused, 9 had moved away, 3 had died, 6 were too ill to participate and 6 were not retrieved); only one subject remained unclassifiable at the end of the study. These subjects were excluded from the analysis.

Rates of missing data were high for diabetes (15.7\%) and cholesterol level $(24.6 \%)$. Importantly, the subjects with missing data for those variables did not differ from the others regarding age, sex, and education (data not shown) but the proportions with dementia were significantly lower (98.0\% vs. $2.0 \%, p=0.004$ and $96.6 \%$ vs. $3.4 \%$, $p=0.005$, respectively).

Factors associated with dementia 
Subjects with and without dementia were compared by univariate analyses as presented in Table 2. Age, female gender, marital status (divorced or widowed) and no schooling were significantly associated with dementia with a $p$-value $<0.05$. Regarding medical variables, a low BMI, the presence of anxiety disorders and depressive symptoms were also associated with dementia. The following life events were associated with dementia in the univariate analysis: death of a parent or having been raised by one parent before 16 years of age, the death of a spouse between the ages of 16 and 64 , and a recent house move or deterioration in financial status.

In the multivariate analysis, the first model included variables occurring prior to the study (Table 3). Independent factors associated with prevalent dementia were, adjusted for study site, age and the death of a parent before the age of 16 . In this model, schooling was no longer significant, with OR remaining greater than one, but with a wide confidence interval, whereas it was a highly significant variable associated with dementia in univariate analysis. Thus an interaction between gender and schooling was suspected and found in a further model: the risk of having dementia was significantly higher for women who had no education compared to those who had at least primary education, while no significant effect of education was found for men. Similarly, among subjects with no education, women were at far higher risk of dementia than men, while the risk was equivalent among subjects with at least primary education (Table 3).

The following model included factors which were found concomitant to the diagnosis of dementia during the study (Table 4). Hypertension and a BMI $<18.5 \mathrm{~kg} \cdot \mathrm{m}^{2}$ were significantly associated with dementia, as were depressive symptoms. The only 
psychosocial factor associated with dementia in this model was having moved residence $(\mathrm{OR}=1.8,95 \% \mathrm{Cl}: 1.1-3.0, \mathrm{p}=0.028)$.

No interaction was found in this model.

\section{Discussion}

To our knowledge, this is the first multicenter population-based study of dementia in central Africa. We showed that beyond traditional risk factors for dementia already found in other epidemiological studies conducted elsewhere, several life events which may be more frequent in these populations are associated with dementia.

The two countries surveyed were chosen for several reasons: dementia in the older general population had never been studied there; moreover, they recently experienced political disturbances and civil wars, leading to interesting research perspectives for the association of dementia and life events. At the time of the study, it was not safe to carry out surveys other than in the capital cities.

Door-to-door sampling could not ensure representative sampling [28]. However, the Bangui participants were not significantly different in age and sex from elderly people living in the $3^{\text {rd }}$ district ( $p>0.05$ for each age group, and $p=0.94$ for sex) [11] and the Brazzaville participants from the $4^{\text {th }}$ district did not differ in sex ratio from the elderly people living in Brazzaville as a whole ( $p>0.05)$ [12]. Ethnic characteristics of our samples were faithful to the cities' overall characteristics. Some ethnic groups might have been over-represented, such as Bacongos in Brazzaville, resulting from the geographical localisation of the city in the country. 
The CSI-D cognitive test was chosen for its relevance and adaptability in populations with different socioeconomic and linguistic backgrounds [29]. It is commonly used in studies carried out in developing countries with low rates of literacy, especially in Nigeria [8] and Benin [9] in Africa, and by the 10/66 Dementia Research Group. We used the same cut-off for the CSI-D cognitive part as successfully used in a previous study in Benin [10]. We also included the FWT, allowing rapid screening of patients for AD. The threshold of 10 was validated in the general population, with a maximal sensitivity of $63 \%$, specificity of $91.1 \%$ and a minimum of false negative and false positive subjects [30]. This version of the verbal memory test based on oral language produces accurate results in illiterate or poorly educated subjects. The combination of the two tests for screening elderly people has been validated in Benin; neuropsychological testing in 50 elderly people negative to screening found no additional cases of dementia [10].

We acknowledge that the number of subjects was guided by the estimation of dementia prevalence, which was the first aim of the study. The design does not allow us to determine risk factors for dementia, but does identify several factors which might be associated with an increased or decreased risk of dementia in these populations. These are the first such findings in for this region of sub-Saharan Africa.

The choice of factors to investigate was guided by the feasibility of data collection in the specific environment of low-income African countries.

Worldwide, age is the most consistent risk factor for dementia [31], and the prevalence and incidence generally increase as populations grow older $[32,33,34]$. In 
this cohort, the prevalence of dementia increased dramatically with age [26]. Age determination is critical in epidemiological studies, but is not always easy when working with low-income populations. In this study, a reliable age for each participant was obtained from official documents and informant reporting, followed by estimation based on historical events $[15,16]$ in discordant cases.

We found a significant interaction between gender and schooling, with a poor education being significantly associated with dementia among women, but not men. Both female gender $[3,4,5,6]$ and low education level [31] have been reported to be risk factors for dementia in African populations. In our sample, primary education was far less common among women (26.2\%) than men (77.8\%), and the gap was even greater when only subjects with dementia were considered $(10.0 \%$ vs. $80.0 \%$, respectively). Men are probably less affected by a lack of formal education because their occupational activities allowed them to compensate for it as they grew older, which was not the case for women. The occupational and leisure activities of poorly educated women are certainly not sufficiently stimulating, unlike those of men in a similar position. A social bias is also possible, as women with access to education are generally from wealthy families. The role of education needs to be thoroughly investigated in countries where schooling was not available for large portions of the population in the past few decades, and may not be a good indicator of cognitive ability.

The death of a parent before the age of 16 was associated with dementia in the first model. Similar results were observed in a Swedish population, with a relative risk of 6.6 of developing severe dementia between the ages of 70 and 79 years [26]. We are 
aware that self-reported biographical events are subject to memorisation bias, especially when they happen early in life. However, the events collected were chosen for their ability to leave their mark on people's minds and there was no other way to obtain this information as no national database is available.

Our finding that malnutrition, indicated by a $\mathrm{BMl}<18.5 \mathrm{~kg} / \mathrm{m}^{2}$, was associated with dementia is in accord with a previous study performed in Nigeria [3] reporting an association between a $\mathrm{BMl}<18.5 \mathrm{~kg} / \mathrm{m}^{2}$ and $\mathrm{AD}$. Relationships between nutritional status and dementia have been more widely investigated in high-income countries. Declining BMI was associated with an increasing risk of incident $A D$ and a faster rate of disease progression in elderly Americans [35]. Some authors also suggested that low BMI, or a faster decline in BMI in later life, may be a preclinical marker of underlying dementia or $\operatorname{AD}[36,37]$. The cross-sectional design of our study does not allow us to draw conclusions about the causal relationship between a low BMI and dementia, and we cannot exclude the possibility that malnutrition was a consequence of dementia.

Regarding cardiovascular risk factors, hypertension was associated with dementia. Several studies in high-income countries have reported an association between hypertension and low cognitive performance $[38,39,40]$. However, we have to interpret this result with caution, as blood pressure was measured only once. The analysis did not highlight other CVD risk factors associated with dementia (i.e. diabetes or obesity). This effect could be due to a selective survival of people not affected by these conditions in these specific populations with low levels of 
healthcare. Interaction of nutritional factors, CVD risk factors and dementia may also be presumed.

In this study, the presence of depressive symptoms at the time of the survey was significantly associated with dementia. This factor has already been associated with cognitive impairment in another elderly African population [9]. The relationship between depression and dementia is discussed in the literature $[41,42,43]$, but it remains controversial whether depressive symptoms represent a risk factor for dementia, or if they are an early symptom of neurodegeneration or a response to first cognitive deficit symptoms. Due to the cross-sectional design of this study, we are unable to assess the temporal association between depression and dementia.

Change of residence was significantly associated with dementia in our model. This life event requires adaptations to daily living. It can be traumatic and lead to increased stress for elderly people [26]. The association between moving and dementia is in accordance with the hypothesis that such events may be involved in the dementia process and could trigger cognitive decline [44,45]. No stressful events have been previously reported to be associated with dementia in African studies. However, we cannot rule out the possibility that the change of residence of the elderly was consequent to the occurrence of dementia.

With regard to statistical analysis, we chose to combine $A D$ and $\mathrm{VaD}$ as the diagnosis of dementia was mainly clinical, without using cerebral imaging or laboratory investigation to confirm the subtype of dementia. Moreover, given the low number of subjects with dementia, distinguishing between the conditions could have 
led to low statistical power. Studying the severity of cognitive impairment was not relevant as validated scales measuring cognitive decline are not available in these populations.

We are aware of the high number of independent variables studied in this study, but colinearity was not an issue in the analyses.

Our study has several limitations. We cannot exclude a lack of power regarding two measures: diabetes and high blood cholesterol. Indeed, they both have a high rate of missing data in Bangui due to problems inherent to specific technical issues encountered in Africa. Because it is a cross-sectional study, the temporality of the associations found cannot be assessed. We also acknowledge that the absence of ApoE genotyping is a limit to our study. High frequencies of the ApoE $\varepsilon 4$ allele have been reported in Pygmies in the Central African Republic (40.7\%) and Bantu (29\%) populations [46].

\section{Conclusion}

This study identified seven variables independently associated with dementia in older Central Africans residing in two large cities. Most are consistent with the worldwide literature (age, female gender, low level of education, hypertension, low BMI and depressive symptoms) but the effects of stressful events which may differ in these specific global regions are the most original findings. Factors associated with dementia in African countries seem different from established factors in high-income countries and need further longitudinal study. 


\section{Acknowledgements}

The authors thank the health ministries of the Central African Republic and the Republic of Congo, and Bangui and Marien Ngouabi (Brazzaville) Universities for their moral support. We also thank all the participants who made these surveys possible: the investigators, the staffs of Bangui and Brazzaville hospitals for their assistance, and the elderly people and their families who devoted time to the study. We particularly acknowledge Miss Anaïs Labrunie for her help with statistical analysis.

The project was funded by the French Ministry of Foreign Affairs as part of the "Coopération pour la Recherche Universitaire et Scientifique" programme (CORUS 6024-4). These investigations were also supported by the Fondation pour la Recherche Médicale and the Doctoral School of Limoges University.

\section{Disclosure}

The authors report no conflict of interest. 


\section{References}

[1] Prince M, Jackson J. World Alzheimer Report. Alzheimer's Disease International. London. 2009. http://www.alz.co.uk/research/files/World 20Alzheimer\%20Report.pdf (accessed Nov 19, 2009).

[2] Qu C, De Ronchi D, Fratiglioni L. The epidemiology of the dementias: an update. Curr Opin Psychiatry 2007;20:380-5.

[3] Ochayi B, Thacher TD. Risk factors for dementia in central Nigeria. Aging Ment Health 2006 ; 10:616-20.

[4] Hall K, Gureje O, Gao S, Ogunniyi A, Hui SL, Baiyewu O, Unverzagt FW, Oluwole S, Hendrie HC. Risk factors and Alzheimer's disease: a comparative study of two communities. Aust N Z J Psychiatry 1998; 32:698-706.

[5] Ogunniyi A, Baiyewu O, Gureje O, Hall KS, Unverzagt F, Siu SH, Gao S, Farlow M, Oluwole OS, Komolafe O, Hendrie HC. Epidemiology of dementia in Nigeria: results from the Indianapolis-lbadan study. Eur $J$ Neurol 2000; 7:485-90.

[6] Ogunniyi A, Hall KS, Gureje O, Baiyewu O, Gao S, Unverzagt FW, SmithGamble V, Evans RE, Dickens J, Musick BS, Hendrie HC. Risk factors for incident Alzheimer's disease in African Americans and Yoruba. Metab Brain Dis 2006; $21: 235-40$.

[7] Gureje O, Ogunniyi A, Kola L. The profile and impact of probable dementia in a sub-Saharan African community: Results from the Ibadan Study of Aging. J Psychosom Res 2006; 61:327-33.

[8] Osuntokun BO, Sahota A, Ogunniyi AO, Gureje O, Baiyewu O, Adeyinka A, Oluwole SO, Komolafe O, Hall KS, Unverzagt FW, Hui SL, Yang M, 
Hendrie HC. Lack of an association between apolipoprotein E epsilon 4 and Alzheimer's disease in elderly Nigerians. Ann Neurol 1995;38:463-465.

[9] Gureje O, Ogunniyi A, Baiyewu O, Price B, Unverzagt FW, Evans RM, Smith-Gamble V, Lane KA, Gao S, Hall KS, Hendrie HC, Murrell JR. APOE epsilon4 is not associated with Alzheimer's disease in elderly Nigerians. Ann Neurol 2006; 59:182-5.

[10] Guerchet M, Houinato D, Paraiso MN, von Ahsen N, Nubukpo P, Otto M, Clément J-P, Preux P-M, Dartigues J-F. Cognitive impairment and dementia in elderly people living in rural Benin, West Africa. Dement Geriatr Cogn Disord 2009; 27:34-41.

[11] Recensement Général de la Population et de l'Habitat, République Centrafricaine, 2006.

[12] Recensement Général de la Population et de l'Habitat 2007, Centre National de la Statistique et des Etudes Economiques, Congo, 2010.

[13] World Health Organization, Data from the Global Health Observatory, Country Health Profile, http://www.who.int/countries/. Accessed the $30^{\text {th }}$ August 2010.

[14] United Nations Development Program, Human Development Report 2009, Overcoming barriers: Human mobility and development, http://hdr.undp.org/en/reports/global/hdr2009/. Accessed the $16^{\text {th }}$ August 2011.

[15] Ogunniyi O, Osuntokun BO. Determination of ages of elderly Nigerians through historical events: validation of Ajayi-Igun 1963 listings. West Afr J Med 1993;12:189-190. 
[16] Paraïso MN, Houinato $D$, Guerchet $M$, Aguèh V, Nubukpo $P$, Preux P-M, Marin B. Validation of the use of historical events to estimate the age of subjects aged 65 years and over in Cotonou (Benin). Neuroepidemiology 2010;35:12-16.

[17] Hall KS, Hugh C, Hendrie HC, Brittain HM, Norton JA, Rodgers DD, Prince CS, Pillay N, Blue AW, Kaufert JN, Nath A, Shelton P, Postl BD, Osuntokun BO. The development of a dementia screening interview in two distinct languages. Int J Meth Psychiatr Res 1993;3:1-28.

[18] Dubois B, Touchon J, Portet F, Ousset PJ, Vellas B, Michel B ."The 5 words": a simple and sensitive test for the diagnosis of Alzheimer's disease. Presse Med 2002;31:1696-1699.

[19] Grober E, Buschke H, Crystal H, Bang S, Dresner R. Screening for dementia by memory testing. Neurology 1988;38:900-903.

[20] Zazzo R. Test des deux barrages. Actualités Pédagogiques et Psychologiques, vol 7. Neuchâtel : Delachaux et Niestlé, 1974.

[21] Isaacs B, Kennie AT. The Set test as an aid to the detection of dementia in old people. Br J Psychiatry 1973;123:467-470.

[22] American Psychiatric Association: Diagnostic and statistical manual of mental disorders. 4th ed. 1994. Washington.

[23] McKhann G, Drachman D, Folstein M, Katzman R, Price D, Stadlan EM. Clinical diagnosis of Alzheimer's disease: report of the NINCDS-ADRDA Work Group under the auspices of the Department of Health and Human Services Task Force on Alzheimer's disease. Neurology 1984;34:939-944.

[24] Hachinski VC, Iliff LD, Zilhka E, et al. Cerebral blood flow in dementia. Arch Neurol 1975;32:632-637. 
[25] Goldberg D, Bridges K, Duncan-Jones P, Grayson D. Detecting anxiety and depression in general medical settings. Br Med J 1988;297:897-899.

[26] Persson G, Skoog I. A prospective population study of psychosocial risk factors for late onset dementia. Int J Geriatr Psychiatry 1996;11:15-22.

[27] Guerchet M, M'belesso P, Mouanga AM, Bandzouzi B, Tabo A, Houinato DS, Paraïso MN, Cowppli-Bony P, Nubukpo P, Aboyans V, Clément JP, Dartigues JF, Preux PM. Prevalence of dementia in elderly living in two cities of Central Africa: the EDAC survey. Dement Geriatr Cogn Disord 2010;30:261-268.

[28] Prince M. Methodological issues for population-based research into dementia in developing countries. A position paper from the 10/66 Dementia Research Group. Int J Geriatr Psychiatry 2000;15:21-30.

[29] Hall KS, Gao S, Emsley CL, et al. Community screening interview for dementia (CSI-D), Performance in five disparate study sites. Int J Geriat Psychiatry 2000;15:521-531.

[30] Cowppli-Bony P, Fabrigoule C, Letenneur L, Ritchie K, Alpérovitch A, Dartigues JF, Dubois B. Validity of the five-word screening test for Alzheimer's disease in a population based study. Rev Neurol (Paris) 2005; $161: 1205-1212$.

[31] Kalaria RN, Maestre GE, Arizaga R, Friedland RP, Galasko D, Hall K, Luchsinger JA, Ogunniyi A, Perry EK, Potocnik F, Prince M, Stewart R, Wimo A, Zhang ZX, Antuono P; World Federation of Neurology Dementia Research Group.Alzheimer's disease and vascular dementia in developing countries: prevalence, management, and risk factors. Lancet Neurol 2008;7:812-826. 
[32] Launer LJ, Andersen K, Dewey ME, Letenneur L, Ott A, Amaducci LA, Brayne C, Copeland JR, Dartigues JF, Kragh-Sorensen P, Lobo A, Martinez-Lage JM, Stijnen T, Hofman A. Rates and risk factors for dementia and Alzheimer's disease: results from EURODEM pooled analyses. EURODEM Incidence Research Group and Work Groups. European Studies of Dementia. Neurology 1999;52:78-84.

[33] Plassman BL, Langa KM, Fisher GG, Heeringa SG, Weir DR, Ofstedal MB, Burke JR, Hurd MD, Potter GG, Rodgers WL, Steffens DC, Willis RJ, Wallace RB. Prevalence of dementia in the United States: the aging, demographics, and memory study. Neuroepidemiology 2007;29:125-132.

[34] Llibre Rodriguez JJ, Ferri CP, Acosta D, Guerra M, Huang Y, Jacob KS, Krishnamoorthy ES, Salas A, Sosa AL, Acosta I, Dewey ME, Gaona C, Jotheeswaran AT, Li S, Rodriguez D, Rodriguez G, Kumar PS, Valhuerdi A, Prince M; 10/66 Dementia Research Group. Prevalence of dementia in Latin America, India, and China: a population-based cross-sectional survey. Lancet 2008; 9; 372(9637): 464-474.

[35] Buchman AS, Wilson RS, Bienias JL, Shah RC, Evans DA, Bennett DA. Change in body mass index and risk of incident Alzheimer disease. Neurology 2005;65:892-897.

[36] Hughes TF, Borenstein AR, Schofield E, Wu Y, Larson EB. Association between late-life body mass index and dementia: The Kame Project. Neurology 2009;72:1741-1746.

[37] Chu LW, Tam S, Lee PW, Yik PY, Song Y, Cheung BM, Lam KS. Late-life body mass index and waist circumference in amnestic mild cognitive impairment and Alzheimer's disease. J Alzheimers Dis 2009;17:223-232. 
[38] André-Petersson L, Hagberg B, Janzon L, Steen G. A comparison of cognitive ability in normotensive and hypertensive 68-year-old men: results from population study 'men born in 1914' in Malmö, Sweden. Exp Aging Res 2001;27:319-340.

[39] Budge MM, de Jager C, Hogervorst E, Smith AD. Total plasma homocysteine, age, systolic blood pressure, and cognitive performance in older people. J Am Geriatr Soc 2002;50:2014-2018.

[40] Kuo HK, Sorond F, Iloputaife I, Gagnon M, Milberg W, Lipsitz LA. Effect of blood pressure on cognitive functions in elderly persons. J Gerontol A Biol Sci Med Sci 2004;59:1191-1194.

[41] Tsuno N, Homma A. What is the association between depression and Alzheimer's disease? Expert Rev Neurother 2009;9:1667-1676.

[42] Panza F, Frisardi V, Capurso C, D'Introno A, Colacicco AM, Imbimbo BP, Santamato A, Vendemiale G, Seripa D, Pilotto A, Capurso A, Solfrizzi V. Late-life depression, mild cognitive impairment, and dementia: possible continuum? Am J Geriatr Psychiatry 2010;18:98-116.

[43] Jorm AF. Is depression a risk factor for dementia or cognitive decline? A review. Gerontology 2000;46:219-27.

[44] Letenneur L, Gilleron V, Commenges D, Helmer C, Orgogozo JM, Dartigues JF. Are sex and educational level independent predictors of dementia and Alzheimer's disease? Incidence data from the PAQUID project. J Neurol Neurosurg Psychiatry 1999;66:177-183.

[45] Ngandu T, von Strauss E, Helkala EL, Winblad B, Nissinen A, Tuomilehto $J$, Soininen H, Kivipelto M. Education and dementia: what lies behind the association? Neurology 2007;69:1442-1450. 
[46] Singh PP, Singh M, Mastana SS. APOE distribution in world distribution with new data from India and the UK. Ann Hum Biol 2006;33:279-308. 
Figure 1: Flow diagram of EDAC study in Bangui and Brazzaville, 2008-2009.

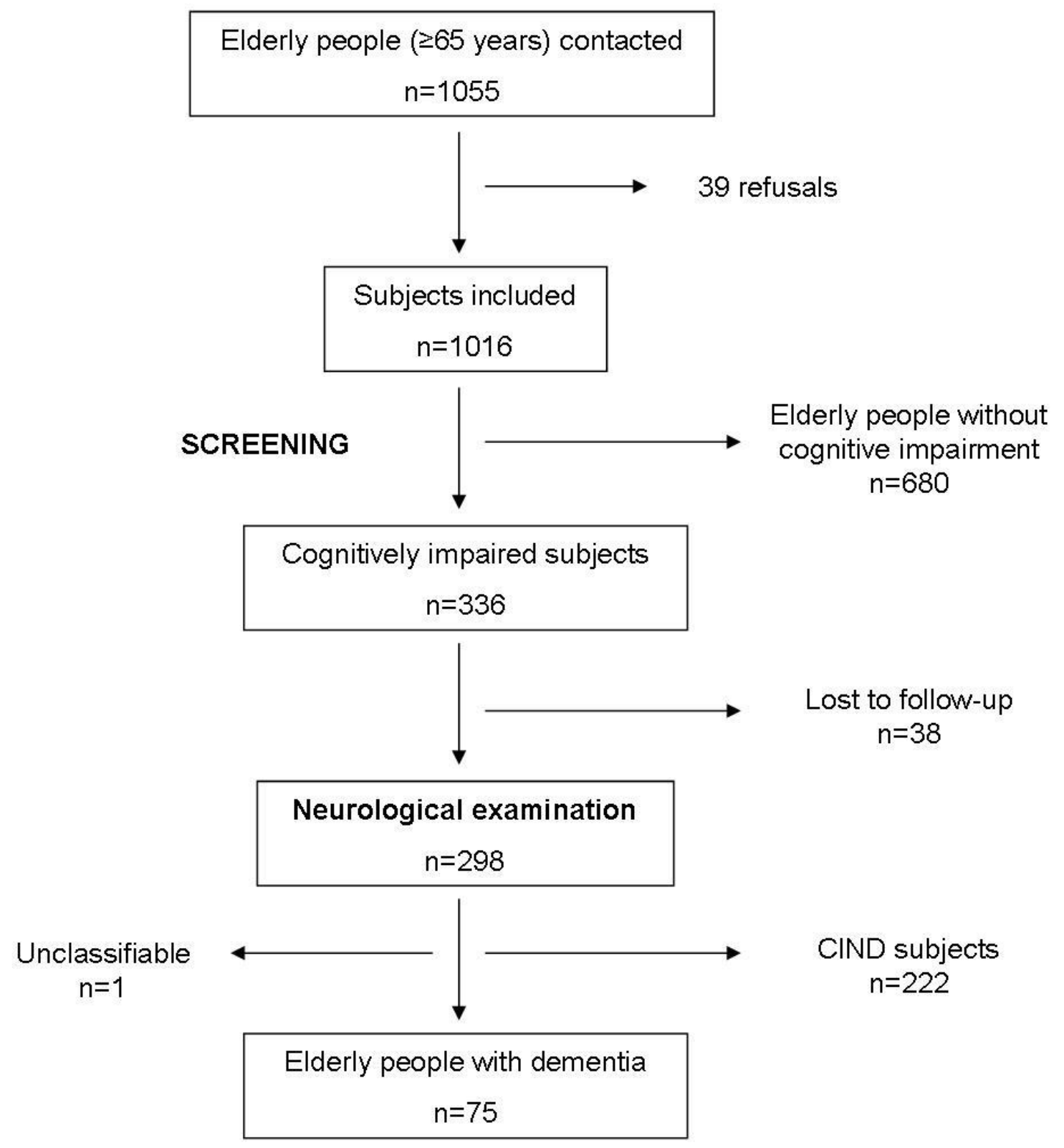


Table 1: Characteristics of the population studied according to dementia and city,

EDAC survey, Bangui \& Brazzaville, 2008-2009

\begin{tabular}{|c|c|c|c|c|c|c|c|c|}
\hline & & \multicolumn{2}{|c|}{ Both } & \multicolumn{2}{|c|}{ Bangui } & \multicolumn{2}{|c|}{ Brazzaville } & \multirow{2}{*}{$\begin{array}{c}\text { Missing } \\
\text { data }\end{array}$} \\
\hline & & $\mathrm{n}$ & $\%$ & $\mathrm{n}$ & $\%$ & $\mathrm{n}$ & $\%$ & \\
\hline \multirow{4}{*}{$\begin{array}{l}\text { Female sex } \\
\text { Age (years) }\end{array}$} & & 600 & 59.1 & 278 & 56.1 & 322 & 61.9 & 0 \\
\hline & $65-74$ & 608 & 59.8 & 334 & 67.3 & 274 & 52.7 & \\
\hline & $75-84$ & 341 & 33.6 & 138 & 27.8 & 203 & 39.0 & 0 \\
\hline & 85 and over & 67 & 6.6 & 24 & 4.8 & 43 & 8.3 & \\
\hline \multirow[t]{4}{*}{ Marital status } & Married & 402 & 39.6 & 204 & 41.1 & 198 & 38.1 & \\
\hline & Divorced & 79 & 7.8 & 36 & 7.3 & 43 & 8.3 & 0 \\
\hline & Widowed & 501 & 49.3 & 234 & 47.2 & 267 & 51.4 & \\
\hline & Single & 34 & 3.4 & 22 & 4.4 & 12 & 2.3 & \\
\hline \multicolumn{2}{|c|}{ Schooling (primary or higher) } & 480 & 47.3 & 214 & 43.3 & 266 & 51.2 & 2 \\
\hline \multirow[t]{5}{*}{ Occupation } & Employee & 319 & 31.4 & 139 & 28.0 & 180 & 34.6 & \\
\hline & Storekeeper/craftsman & 238 & 23.4 & 72 & 14.5 & 166 & 31.9 & 0 \\
\hline & Farmer/breeder & 347 & 34.2 & 221 & 44.6 & 126 & 24.2 & \\
\hline & No job & 18 & 1.8 & 8 & 1.6 & 10 & 1.9 & \\
\hline & Other & 94 & 9.3 & 56 & 11.3 & 38 & 7.3 & \\
\hline \multirow[t]{4}{*}{ BMI } & $<18.5$ & 190 & 19.2 & 142 & 29.5 & 48 & 9.5 & \\
\hline & $18.5-24 / 9$ & 524 & 52.9 & 284 & 58.9 & 240 & 47.2 & 26 \\
\hline & $25-30$ & 189 & 19.1 & 43 & 8.9 & 146 & 28.7 & \\
\hline & $>30$ & 87 & 8.8 & 13 & 2.7 & 74 & 14.6 & \\
\hline \multicolumn{2}{|l|}{ Diabetes } & 141 & 16.5 & 27 & 7.9 & 114 & 22.2 & 160 \\
\hline \multicolumn{2}{|l|}{ Hypertension } & 545 & 53.8 & 256 & 51.8 & 289 & 55.7 & 3 \\
\hline \multicolumn{2}{|c|}{ High blood cholesterol } & 21 & 2.7 & 3 & 0.9 & 18 & 4.0 & 250 \\
\hline \multicolumn{2}{|l|}{ Head injury } & 72 & 7.1 & 48 & 9.7 & 24 & 4.7 & 7 \\
\hline \multirow[t]{3}{*}{ Alcohol } & Never & 420 & 41.4 & 182 & 36.8 & 238 & 45.8 & \\
\hline & Sometimes & 483 & 47.6 & 256 & 51.8 & 227 & 43.7 & 2 \\
\hline & Regularly & 111 & 11.0 & 56 & 11.3 & 55 & 10.6 & \\
\hline \multirow[t]{3}{*}{ Tobacco } & Never smoked & 664 & 65.6 & 313 & 63.5 & 351 & 67.5 & \\
\hline & Former smoker & 181 & 17.9 & 53 & 10.8 & 128 & 24.6 & 3 \\
\hline & Current smoker & 168 & 16.6 & 127 & 25.8 & 41 & 7.9 & \\
\hline \multicolumn{2}{|c|}{ Anxiety disorders } & 562 & 55.3 & 381 & 76.8 & 181 & 34.8 & 1 \\
\hline \multicolumn{2}{|c|}{$\begin{array}{l}\text { Depressive symptoms } \\
\text { Before age of }\end{array}$} & 729 & 71.8 & 476 & 96.0 & 253 & 48.7 & 1 \\
\hline \multirow[t]{5}{*}{ 16: } & Death of a parent & 494 & 50.4 & 286 & 61.4 & 208 & 40.4 & 35 \\
\hline & Divorce of parents & 94 & 9.4 & 44 & 9.0 & 50 & 9.7 & 12 \\
\hline & Growing up with one parent & 457 & 45.3 & 258 & 52.2 & 199 & 38.6 & 6 \\
\hline & Different guardians & 340 & 33.7 & 167 & 33.9 & 173 & 33.5 & 6 \\
\hline & Extreme poverty & 384 & 39.3 & 256 & 55.5 & 128 & 24.8 & 38 \\
\hline \multirow[t]{5}{*}{ 16-64: } & Death of a spouse & 407 & 40.6 & 220 & 44.5 & 187 & 36.7 & 13 \\
\hline & Death of a child & 692 & 68.5 & 381 & 77.0 & 311 & 60.4 & 6 \\
\hline & Serious illness in a child & 577 & 57.3 & 307 & 62.4 & 270 & 52.4 & 9 \\
\hline & Arduous manual work & 560 & 55.5 & 334 & 67.8 & 226 & 43.7 & 6 \\
\hline & Shift or piece work & 230 & 22.8 & 93 & 18.8 & 137 & 26.5 & 5 \\
\hline \multirow[t]{8}{*}{ Over 65 : } & Death of spouse & 215 & 21.4 & 117 & 23.7 & 98 & 19.1 & 11 \\
\hline & Physical illness in spouse & 204 & 20.3 & 78 & 15.8 & 126 & 24.6 & 11 \\
\hline & Mental illness in spouse & 21 & 2.1 & 17 & 3.5 & 4 & 0.8 & 11 \\
\hline & Death of a child & 424 & 42.0 & 267 & 53.9 & 157 & 30.5 & 7 \\
\hline & Serious illness in a child & 397 & 39.4 & 227 & 46.0 & 170 & 33.0 & 8 \\
\hline & Death of sibling or friend & 780 & 78.0 & 412 & 85.1 & 368 & 71.3 & 16 \\
\hline & Change of residence & 212 & 21.0 & 122 & 24.7 & 90 & 17.4 & 5 \\
\hline & Financial status deterioration & 612 & 61.1 & 392 & 80.0 & 220 & 43.0 & 14 \\
\hline
\end{tabular}


Table 2: Univariate analysis between dementia and sociodemographic, medical and psychosocial variables, EDAC study, 2008-2009.

\begin{tabular}{|c|c|c|c|c|}
\hline & & OR & $95 \% \mathrm{Cl}$ & $p$-value \\
\hline Age & [(for 10 years) NOT CLEAR] & 2.56 & $1.82-3.59$ & $<0.001$ \\
\hline \multirow[t]{2}{*}{ Sex } & Male & 1.00 & (reference) & \\
\hline & Female & 3.03 & $1.70-5.42$ & $<0.001$ \\
\hline \multirow[t]{2}{*}{ City } & Bangui & 1.00 & (reference) & \\
\hline & Brazzaville & 0.80 & $0.50-1.29$ & 0.366 \\
\hline \multirow[t]{4}{*}{ Marital status } & Married & 1.00 & (reference) & \\
\hline & Single & 0.76 & $0.10-5.91$ & \\
\hline & Divorced & 2.81 & $1.15-6.82$ & 0.004 \\
\hline & Widowed & 2.74 & $1.54-4.90$ & \\
\hline \multirow[t]{2}{*}{ Schooling } & None & 1.00 & (reference) & \\
\hline & Primary education or higher & 3.13 & $1.81-5.40$ & $<0.001$ \\
\hline \multirow[t]{4}{*}{ BMI } & $<18.5$ & 1.93 & $1.13-3.29$ & \\
\hline & $18.5 \leq 24.9$ & 1.00 & (reference) & \\
\hline & $25.0 \leq 29.9$ & 0.89 & $0.45-1.75$ & 0.010 \\
\hline & $\geq 30$ & 0.15 & $0.02-1.13$ & \\
\hline Hypertension & & 1.57 & $0.96-2.56$ & 0.073 \\
\hline Diabetes & & 0.80 & $0.40-1.61$ & 0.541 \\
\hline High blood cholesterol & & 0.50 & $0.07-3.76$ & 0.498 \\
\hline Head injury & & 0.34 & $0.08-1.43$ & 0.142 \\
\hline \multirow[t]{3}{*}{ Alcohol consumption } & Never & 1.00 & (reference) & \\
\hline & Sometimes & 0.75 & $0.45-1.23$ & \\
\hline & Regularly & 0.61 & $0.25-1.49$ & $0.3 / 2$ \\
\hline \multirow[t]{3}{*}{ Tobacco consumption } & Never smoked & 1.00 & (reference) & \\
\hline & Former smoker & 1.26 & $0.70-2.29$ & \\
\hline & Current smoker & 0.89 & $0.45-1.75$ & 0.643 \\
\hline Anxiety disorders & & 2.78 & $1.61-4.80$ & $<0.001$ \\
\hline Depressive symptoms & & 4.17 & $1.89-9.20$ & $<0.001$ \\
\hline \multirow[t]{5}{*}{ Before 16 years old } & Death of one parent & 2.08 & $1.25-3.46$ & 0.005 \\
\hline & Divorce of parents & 1.41 & $0.68-2.94$ & 0.357 \\
\hline & Raised with one parent & 1.69 & $1.04-2.73$ & 0.034 \\
\hline & Raised with other persons & 1.56 & $0.96-2.52$ & 0.071 \\
\hline & Raised in extreme poverty & 1.09 & $0.66-1.78$ & 0.744 \\
\hline \multirow{5}{*}{ 16-64 years: } & Death of a spouse & 1.80 & $1.10-2.93$ & 0.019 \\
\hline & Death of a child & 1.06 & $0.63-1.79$ & 0.812 \\
\hline & Illness of a child & 1.28 & $0.78-2.11$ & 0.316 \\
\hline & Tiring job & 1.22 & $0.75-1.99$ & 0.414 \\
\hline & Working at night & 0.62 & $0.33-1.18$ & 0.146 \\
\hline \multirow[t]{8}{*}{ After 65s: } & Death of a spouse & 1.46 & $0.84-2.54$ & 0.176 \\
\hline & $\begin{array}{l}\text { Serious physical illness of a } \\
\text { spouse }\end{array}$ & 1.11 & $0.61-2.00$ & 0.737 \\
\hline & Mental illness of a spouse & * & * 1.00 & 0.101 \\
\hline & Death of a child & 1.29 & $0.80-2.08$ & 0.303 \\
\hline & Serious illness of a child & 1.09 & $0.67-1.77$ & 0.721 \\
\hline & Death of relatives or friends & 1.83 & $0.92-3.63$ & 0.085 \\
\hline & Moving & 2.10 & $1.26-3.49$ & 0.004 \\
\hline & Change in financial status & 1.74 & $1.02-2.97$ & 0.041 \\
\hline
\end{tabular}

$\mathrm{BMI}=$ Body Mass Index

$\mathrm{OR}=$ odds ratio $; 95 \% \mathrm{Cl}=95 \%$ confidence interval

* the univariate logistic model is not converging because of the quasi-complete separation of data points 
Table 3: Multivariate analysis of risk factors present before the diagnosis of dementia. The EDAC study, 2008-2009.

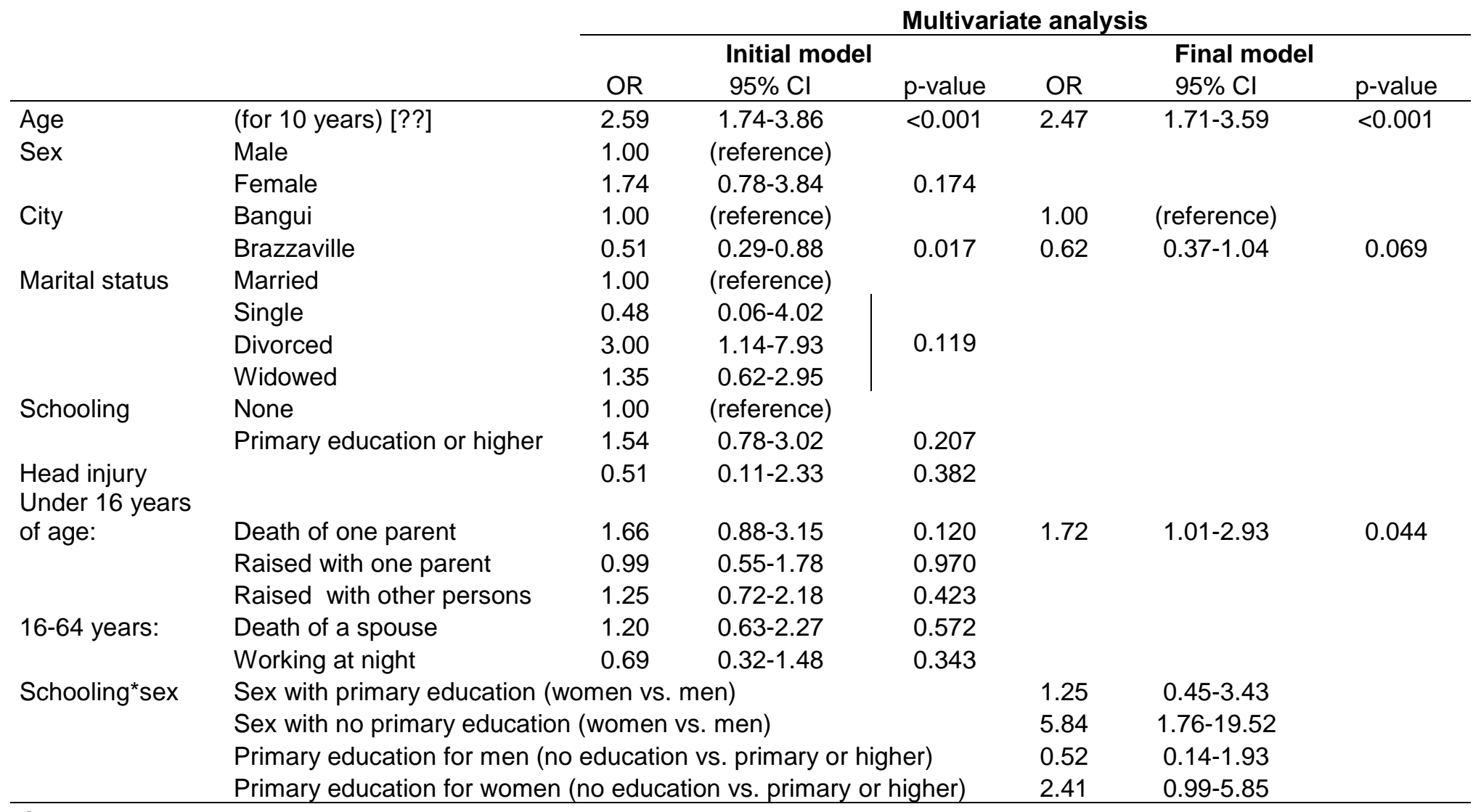

$\mathrm{OR}=$ odds ratio

$95 \% \mathrm{Cl}=95 \%$ confidence interval 
Table 4: Multivariate analysis of factors concomitant to the diagnosis of dementia. The EDAC study. 2008-2009.

\begin{tabular}{|c|c|c|c|c|c|c|c|}
\hline & & \multicolumn{6}{|c|}{ Multivariate analysis } \\
\hline & & \multicolumn{3}{|c|}{ Initial model } & \multicolumn{3}{|c|}{ Final model } \\
\hline & & OR & $95 \% \mathrm{Cl}$ & $\mathrm{p}$-value & OR & $95 \% \mathrm{Cl}$ & $\mathrm{p}$-value \\
\hline Hypertension & & 1.76 & $1.03-3.01$ & 0.039 & 1.72 & $1.03-2.85$ & 0.036 \\
\hline \multirow[t]{4}{*}{$\mathrm{BMI}$} & $<18.5$ & 1.79 & $1.01-3.19$ & \multirow{4}{*}{0.042} & 1.77 & $1.02-3.06$ & \\
\hline & $18.5 \leq 24.9$ & 1.00 & (reference) & & 1.00 & (reference) & \\
\hline & $25.0 \leq 29.9$ & 0.99 & $0.48-2.06$ & & 0.97 & $0.49-1.95$ & 0.042 \\
\hline & $\geq 30.0$ & 0.19 & $0.03-1.44$ & & 0.17 & $0.02-1.30$ & \\
\hline Anxiety disorders & & 1.72 & $0.87-3.39$ & 0.115 & & & \\
\hline Depressive symptoms & & 2.06 & $0.81-5.22$ & 0.128 & 3.50 & $1.56-7.82$ & 0.002 \\
\hline \multirow[t]{4}{*}{ Over 65: } & Death of a spouse & 1.17 & $0.64-2.11$ & 0.609 & & & \\
\hline & Death of relatives or friends & 1.15 & $0.55-2.38$ & 0.712 & & & \\
\hline & Moving & 1.55 & $0.88-2.73$ & 0.127 & 1.79 & $1.06-3.01$ & 0.028 \\
\hline & Change in financial status & 1.22 & $0.69-2.16$ & 0.491 & & & \\
\hline
\end{tabular}

$\mathrm{BMI}=$ Body Mass Index

$\mathrm{OR}=$ odds ratio

$95 \% \mathrm{Cl}=95 \%$ confidence interval 